\title{
Bruk av antipsykotiske depotinjeksjoner
}

\author{
Etterlevelse er et stort problem ved bruk av antipsykotiske legemidler. \\ Derfor ble det i 1960-årene utviklet depotinjeksjoner. Ved å redusere \\ vannløseligheten betydelig har man oppnådd at virkestoffet diffunderer \\ langsomt ut fra innstikksstedet, dermed er terapeutisk serumkonsen- \\ trasjon sikret igjennom hele perioden. Nyere studier viser at slik \\ behandling kan gi redusert risiko for sykehusinnleggelser og tilbakefall \\ av psykoser, sammenliknet med bruk av tabletter.
}

Se også kunnskapsprøve på www.tidsskriftet.no/quiz

\section{Gudrun Høiseth}

gudrun.hoiseth@diakonsyk.no Håvard Bentsen

Senter for psykofarmakologi

Diakonhjemmet Sykehus

Antipsykotiske legemidler er effektive i behandling av schizofreni, og en rekke studier har vist at slike midler både bedrer symptomene og hindrer tilbakefall (1). Bruk av antipsykotika kan imidlertid medføre plagsomme bivirkninger, noe som bidrar til sviktende legemiddeletterlevelse (complicance) - omtrent én av to pasienter med schizofreni tar ikke tablettene som foreskrevet. Allerede etter ti dagers manglende bruk av antipsykotika øker faren for sykehusinnleggelse med $50-80 \%$ (2)

For å løse dette problemet innførte man i 1960-årene depotinjeksjoner. Intramuskulære injeksjoner settes hver 2.-4. uke, og pasienten er sikret terapeutisk vevskonsentrasjon $\mathrm{i}$ hele perioden. Vi vil i denne artikkelen presentere effekt, farmakokinetikk og klinisk bruk av antipsykotiske depotinjeksjoner. Grunnlaget for artikkelen er et litteratursøk i PubMed og et skjønnsmessig utvalg av artikler basert på forfatternes erfaring innen psykiatri og farmakologi.

\section{Effekt og bivirkninger}

I randomiserte forsøk med antipsykotika har injeksjonspreparater stort sett samme kliniske effekt som tilsvarende perorale preparater $(1,3,4)$. Imidlertid er de pasientene som vil ha best nytte av depotinjeksjoner, nemlig de som ikke tar tabletter som foreskrevet, underrepresentert i slike studier. Prospektive observasjonsstudier viser betydelig lavere sannsynlighet (mellom en tredel og halvparten) for innleggelse i psykiatrisk sykehus hos dem som får depotinjeksjoner enn hos dem som bruker det tilsvarende perorale preparatet $(1,5)$.
Depotinjeksjoner forventes stort sett å ha tilsvarende bivirkninger som perorale preparater (6). Ett unntak er akutte og kroniske reaksjoner på innstikksstedet. Disse forekommer ved alle førstegenerasjonsantipsykotika $(<25 \%)$, men er sjeldne ved annengenerasjonsantipsykotika $(<5 \%)(3,6,7)$. Jo hyppigere (dvs. ukentlige) injeksjoner og jo større dose, desto større er risikoen for lokale reaksjoner. Spesielt ved bruk av olanzapin kan det oppstå et postinjeksjonssyndrom, med sentralnervøse symptomer som ved overdose. Dette forekommer etter under $0,1 \%$ av injeksjonene $(6,8)$.

Verdens helseorganisasjon (WHO) fraråder rutinemessig bruk av depotinjeksjoner ved graviditet og amming på grunn av manglende erfaring med sikkerheten. Hvis pasienten alt behandles med et antipsykotikum, vil det tryggeste være å fortsette med det samme under graviditeten $(9,10)$. Dette skulle også gjelde depotpreparater, da de som nevnt ikke gir mer bivirkninger enn peroral medikasjon. Felleskatalogen har samme tekst om graviditet og amming for depotpreparater som for perorale preparater.

\section{Farmakokinetikk}

En rekke førstegenerasjonsantipsykotika, samt de to annengenerasjonsantipsykotiske midlene olanzapin og risperidon, er lansert som depotinjeksjonspreparater (tab 1) (11, 12). Førstegenerasjonsantipsykotika i injeksjonsform er forestret med dekansyre til dekanoater og så løst i en planteolje. Etter en intramuskulær injeksjon vil esteren diffundere langsomt ut av oljen. Risperidon er innkapslet i polymere mikrokuler, som hydrolyseres langsomt in vivo. Olanzapin er et pamoatsalt løst $\mathrm{i}$ vann.

Injeksjon i glutealmuskulaturen anbefales, enten dorso- eller ventroglutealt, og høyre og venstre side må benyttes alternerende (7). Det er viktig at legemidlet ikke settes intravenøst, da dette kan føre til seda- sjon og nedsatt bevissthet. Det er også viktig at injeksjonene settes dypt nok så de ikke går subkutant, det vil si ofte dypere enn $3,5 \mathrm{~cm}$, særlig i glutealmuskulaturen. Subkutane injeksjoner gir en mer uforutsigbar absorpsjon på grunn av varierende blodgjennomstrømming i underhuden. Det må sikres at sykepleieren som setter sprøytene, har fătt god nok opplæring (7).

En fordel ved depotinjeksjoner fremfor tabletter er at førstepassasjeeffekten bortfaller. Pasienten vil derfor eksponeres for en noe høyere dose ved en depotinjeksjon enn ved tilsvarende tablettdosering i løpet av det samme tidsrommet.

Depotinjeksjonspreparatene har en relativt lik farmakokinetisk profil, med størst avgivelse fra depotet rett etter injeksjonen (unntatt risperidon) (6). Konsentrasjonen vil derfor stige den første uken, for deretter å avta med en halveringstid på 2-3 uker (fire uker for olanzapin). Denne halveringstiden vil reflektere både avgivelse fra depotet $\mathrm{og}$ eliminasjon av virkestoffet. Det vil altså ta 2-3 måneder etter behandlingsstart (dvs. 4-5 ganger halveringstiden) før likevektskonsentrasjon er oppnådd, og like lenge til virkestoffet er ute av kroppen etter avsluttet behandling. Risperidon, derimot, vil ha en initial frisetting av $1 \%$ av dosen, mens hovedfrigjøringen finner sted $2-5$ uker etter injeksjonen. Tillegg av peroral risperidon må derfor gis de første tre ukene etter første injeksjon.

Referanseområdet gjelder for perioden 0-2 dager før neste dose, forutsatt oppnådd likevektskonsentrasjon. Serumkonsentrasjonsmålinger bør derfor tas i dette tidsrommet. Referanseområdet for depotpreparatene er det samme som for perorale preparater. For risperidon er det vist at serumkonsentrasjonen er langt mer stabil ved depotinjeksjon med ca. 30\% lavere maksimumskonsentrasjon enn ved bruk av peroral formulering (3).

\section{Hovedbudskap}

- Mange pasienter vegrer seg for å ta antipsykotiske legemidler i tablettform

- Ved depotinjeksjoner oppnås terapeutisk serumkonsentrasjon over lengre tid

- Depotinjeksjoner kan redusere risikoen for sykehusinnleggelse og tilbakefall av psykoser 
Tabell 1 Oversikt over antipsykotiske legemidler som selges som depotinjeksjon i Norge. Halveringstiden $\left(T_{1 / 2}\right)$ reflekterer både avgivelse fra injeksjonsstedet og eliminasjon fra plasma

\begin{tabular}{|c|c|c|c|c|c|}
\hline Virkestoff & Produktnavn & Anbefalt vedlikeholdsdose & $T_{\text {maks }}$ & $\mathrm{T}_{1 / 2}$ (uker) & $\begin{array}{l}\text { Referanseområde } \\
\qquad\left(\mathrm{nmol} / \mathrm{l}^{1}\right.\end{array}$ \\
\hline \multicolumn{6}{|l|}{ Førstegenerasjon } \\
\hline Perfenazin & Trilafon dekanoat & $78-156$ mg hver 3.- 4 . uke & 7 dager & $<1$ & $1-7$ \\
\hline Zuklopentixol & Cisordinol Depot & 200-400 mg hver 2.-4. uke & 3-7 dager & 3 & $5-35$ \\
\hline Flupentixol & Fluanxol Depot & 20-200 mg hver 2.-4. uke & $4-10$ dager & 3 & $1-15$ \\
\hline Haloperidol & Haldol depot & < 300 mg hver 4. uke & 3-9 dager & 3 & $2-25$ \\
\hline \multicolumn{6}{|l|}{ Annengenerasjon } \\
\hline Olanzapin & ZypAdhera & 150-300 mg hver 2. uke ${ }^{2}$ & $1-4$ uker & 4 & $30-200$ \\
\hline Risperidon & Risperdal Consta & 25-50 mg hver 2. uke & 2-5 uker & $<1$ & $20-120^{3}$ \\
\hline
\end{tabular}

Det er også høyere ratio mellom moderstoff og metabolitt enn ved peroral behandling.

\section{Klinisk bruk}

Alle pasienter der langtidsbehandling med antipsykotiske legemidler er indisert, er kandidater for depotinjeksjoner (4). Hovedgrunnen til å foreskrive slik behandling er sviktende legemiddeletterlevelse. Dette kan vise seg som gjentatte episoder med symptomforverring, fallende eller vekslende serumkonsentrasjon eller at pasienten nekter å ta nødvendig medikasjon (vedtak om tvungen psykiatrisk behandling). En annen grunn kan være at pasienten ønsker depotinjeksjoner i stedet for tabletter av bekvemmelighetshensyn. Pasient og pårørende bør informeres om slik behandling som en valgmulighet og om fordeler og ulemper. Den kan foreskrives ved første sykehusopphold eller senere $(4,5)$.

Grunner til ikke å forskrive depotmedikasjon kan være at pasienten tar sine tabletter som foreskrevet, at man foretrekker et antipsykotikum som ikke finnes i depotformulering, av hensyn til bivirkningsrisikoen (slik som aripiprazol) eller av hensyn til forventet effekt (slik som klozapin).

En studie med pasienter med schizofreni viste at jo mer erfaring pasientene hadde med depotinjeksjoner, desto mer positive var de (73\% av dem som brukte versus $23 \%$ av dem som aldri hadde brukt depotpreparat) (13). Noen leger vegrer seg for å forskrive depotpreparater fordi de tror pasientene ikke ønsker dem (pga. stigmatisering eller frykt for bivirkninger), fordi behandlingen krever mer ressurser eller fordi de ikke ser nødvendigheten av depotpreparater (14). I USA og Storbritannia er $25-35 \%$ av forskrevet antipsykotika depotformuleringer (15). I Norge brukte 18 menn og 22 kvinner per 1000 innbyggere et antipsykotisk legemiddel i 2010, med olanzapin som det mest solgte. Av total mengde forskrevet perfenazin, zuklopentixol og risperidon var henholdsvis $25 \%, 45 \%$ og $14 \%$ i form av depotpreparat (i 2009). I perioden 2004-09 hadde andelen depotformulering økt med henholdsvis $30 \%, 25 \%$ og $225 \%$ (personlig meddelelse Elisabeth Eriksen, Reseptregisteret).

Legemiddelkostnadene er større ved bruk av depotinjeksjoner enn ved bruk av tabletter. Det er vist at samfunnets utgifter likevel blir mindre, mest på grunn av færre sykehusinnleggelser (16). Ved enkelte sykehus er det opprettet egne poliklinikker for oppfølging av pasienter som står på depotinjeksjoner med antipsykotika.

Depotbehandling med antipsykotika skal bare startes etter at den perorale formuleringen er prøvd (6). Ved overgang fra tabletter til injeksjon bør man fortsette med tabletter i avtakende doser i 3-4 uker. På grunn av høyere biotilgjengelighet kan døgndosen antipsykotika være lavere når det brukes injeksjoner istedenfor tabletter. Råd om praktisk gjennomføring av oppstart og vedlikeholdsbehandling for de enkelte preparater er gitt i Felleskatalogen. Generelt skal laveste effektive dose benyttes, for å minske risikoen for bivirkninger. Injeksjonen skal settes 1-2 ganger per måned (tab 1). Hyppigere dosering øker faren for injeksjonsrelaterte bivirkninger. Dosering hver annen uke gir mindre fluktuasjon i serumkonsentrasjon enn dosering hver fjerde uke, men kliniske følger av dette er ikke rapportert $(6,8)$.

Ofte kombineres depotantipsykotika med andre typer antipsykotika, enten som depotinjeksjoner eller tabletter. Dette frarådes fordi nytteeffekten er dårlig dokumentert, og fordi faren for uforutsigbare og alvorlige interaksjoner øker ved slik kombinasjonsbehandling (12).

\section{Konklusjon}

Antipsykotiske depotinjeksjoner øker legemiddeletterlevelsen og minsker faren for sykehusinnleggelser i forhold til peroral be- handling med tilsvarende virkestoff. Dette tilsier at leger bør overveie depotbehandling ved psykoser.

\section{Gudrun Høiseth (f. 1976)}

er lege i spesialisering i klinisk farmakologi. Hun har en doktorgrad i alkoholmetabolisme. Ingen oppgitte interessekonflikter.

\section{Håvard Bentsen (f. 1956)}

er dr.med., spesialist i psykiatri og klinisk farmakologi, med spesialkompetanse innen schizofreni- og lipidforskning. Han er overlege ved Senter for Psykofarmakologi, Diakonhjemmet Sykehus.

Oppgitte interessekonflikter: Forfatteren har fått bidrag til nettside/foredrag/konferansedeltakelse fra Astra Zeneca, Bristol-Myer Squibb, Lundbeck og Pfizer.

\section{Litteratur}

1. Haddad PM, Taylor M, Niaz OS. First-generation antipsychotic long-acting injections $v$. oral antipsychotics in schizophrenia: systematic review of randomised controlled trials and observational studies. Br J Psychiatry Suppl 2009; 52: S20-8.

2. Law MR, Soumerai SB, Ross-Degnan D et al. A longitudinal study of medication nonadherence and hospitalization risk in schizophrenia. J Clin Psychiatry 2008; 69: 47-53.

3. Fleischhacker WW. Second-generation antipsychotic long-acting injections: systematic review. Br J Psychiatry Suppl 2009: 52: S29-36.

4. Kane JM, Garcia-Ribera C. Clinical guideline recommendations for antipsychotic long-acting injections. Br J Psychiatry Suppl 2009; 52: S63-7.

5. Tiihonen J, Haukka J, Taylor $M$ et al. A nationwide cohort study of oral and depot antipsychotics after first hospitalization for schizophrenia. Am J Psychiatry 2011; 168: 603-9.

6. Taylor D. Psychopharmacology and adverse effects of antipsychotic long-acting injections: a review. Br J Psychiatry Suppl 2009: 52: S13-9.

7. Gray R, Spilling R, Burgess D et al. Antipsychotic long-acting injections in clinical practice: medica tion management and patient choice. Br J Psychiatry Suppl 2009; 52: S51-6. 
8. Kane JM, Detke HC, Naber D et al. Olanzapine long-acting injection: a 24-week, randomized, double-blind trial of maintenance treatment in patients with schizophrenia. Am J Psychiatry 2010; 167: 181-9.

9. ACOG Committee on Practice Bulletins--Obstetrics. ACOG Practice Bulletin: Clinical management guidelines for obstetrician-gynecologists number 92. April 2008 (replaces practice bulletin number 87. November 2007). Use of psychiatric medications during pregnancy and lactation. Obstet Gynecol 2008; 111: 1001-20.

10. Gentile S. Antipsychotic therapy during early and late pregnancy. A systematic review. Schizophr Bull 2010; 36: 518-44
late pregnancy. A syst

11. Hiemke C, Baumann P, Bergemann $\mathrm{N}$ et al. AGNP Consensus guidelines for therapeutic drug monitoring in psychiatry: update 2011. Pharmacopsychiatry 2011; 44: 195-235.

12. Barnes TR, Paton C. Antipsychotic polypharmacy in schizophrenia: benefits and risks. CNS Drugs 2011; 25: 383-99.

13. Heres S, Schmitz FS, Leucht S et al. The attitude of patients towards antipsychotic depot treatment. Int Clin Psychopharmacol 2007; 22: 275-82.

14. Hamann J, Mendel R, Heres S et al. How much more effective do depot antipsychotics have to be compared to oral antipsychotics before they are prescribed? Eur Neuropsychopharmacol 2010; 20 : 276-9.

15. Barnes TR, Shingleton-Smith A, Paton C. Antipsychotic long-acting injections: prescribing practice in the UK. Br J Psychiatry Suppl 2009; 52: S37-42.

16. Edwards NC, Locklear JC, Rupnow MF et al. Cost effectiveness of long-acting risperidone injection versus alternative antipsychotic agents in patients with schizophrenia in the USA. Pharmacoeconomics 2005; 23 (suppl 1): 75-89.

Mottatt 22.6. 2011, første revisjon innsendt 18.10. 2011, godkjent 10.11. 2011. Medisinsk redaktør Petter Gjersvik. 